\title{
MENINGKATKAN KEMAMPUAN MOTORIK KASAR ANAK USIA DINI
}

\section{MELALUI PERMAINAN BOLA ESTAFET KELOMPOK B TK KARTIKA VI-15 BIAK} KABUPATEN BIAK NUMFOR

\author{
Darlin') \& Busyairi Ahmad $^{2)}$ \\ 1,2Fakultas Ilmu Sosial dan IImu Politik IISIP Yapis Biak \\ Email: ${ }^{1}$ darlinelin1981@gmail.com \& ${ }^{2}$ busyairiahmad90@gmail.com
}

\begin{abstract}
This Research aims to improve children's interpersonal skills trough activities that tell stories in group B TK Kartika VI-15, Biak Numfor. The subjects in this research were students in group B of TK Kartika VII-15 Biak Numfor. This type of research is Class Action Research. Based on the analysis of observational data on teacher teaching activities in the first cycle of 14 aspects, the achievement percentage was $71.43 \%$ or 10 aspects, and the percentage of inaccessibility was $28.57 \%$ or 4 aspects. $64.29 \%$ or 9 aspects achieved and the percentage of inaccessibility was $35.71 \%$ or 5 aspects. While in the second cycle the results of teacher teaching activities increased to $92.86 \%$ or 13 aspects achieved and the percentage of inaccessibility was $7.14 \%$ or 1 aspect. While the learning activities of students in the second cycle increased to $85.71 \%$ or 12 aspects achieved and the percentage of inaccessibility was $14.29 \%$ or 2 aspects.
\end{abstract}

Keywords: Rugged Motorics \& Relay Ball Games

\section{PENDAHULUAN}

Undang-Undang Pendidikan Republik Indonesia No. 20 Tahun 2003 tentang Sistem Pendidikan Nasional Pasal 1 ayat 14 menyatakan bahwa Pendidikan Anak Usia Dini adalah suatu upaya pembinaan yang ditujukan kepada anak sejak lahir sampai dengan usia enam tahun yang dilakukan melalui pemberian rangsangan pendidikan untuk membantu pertumbuhan dan perkembangan jasmani dan rohani agar anak memiliki kesiapan dalam memasuki pendidikan lebih lanjut (Depdiknas, 2003).

Masa anak usia dini sering disebut dengan istilah "golden age" atau masa emas. Pada masa ini hampir semua potensi anak mengalami masa peka untuk tumbuh dan berkembang secara cepat. Perkembangan setiap anak itu berbeda-beda tidak sama antara anak yang satu dengan anak yang lainnya. Makanan yang bergizi dan seimbang serta stimulasi yang intensif sangat dibutuhkan untuk pertumbuhan dan perkembangan anak tersebut.

Perkembangan motorik dapat juga disebut sebagian perkembangan dari unsur kematangan dan pengendalian gerak tubuh. Perkembangan motorik ini erat kaitannya dengan http://ejurnal.binawakya.or.id/index.php/MBI Open Journal Systems perkembangan pusat motorik di otak. Oleh karena itu, setiap gerakan yang dilakukan anak sesederhana apapun, sebenarnya merupakan pola interaksi yang kompleks dan sistem dalam tubuh yang dikontrol otak, Kematangan syaraf akan mempengaruhi gerakan motorik anak (Syafi'i, 2007: 1.3)

Prinsip perkembangan motorik menurut Yudha M. Saputra dan Rudyanto (2005: 116) adanya suatu perubahan baik fisik maupun psikis sesuai dengan masa pertumbuhan serta perkembangan motorik sangat dipengaruhi oleh gizi, status kesehatan, dan perlakuan motorik yang sesuai dengan masa perkembangannya.

Seiring dengan pertumbuhan fisiknya yang beranjak matang, maka perkembangan motorik anak sudah dapat terkoordinasi dengan baik setiap gerakan anak sudah selaras dengan kebutuhan atau minatnya. Anak menggerakkan anggota badannya dengan tujuan yang jelas seperti menggerakkan tangan untuk menulis, menggambar, mengambil makanan, menggerakan kaki untuk menendang bola, lari mengejar teman dan sebagainya (Syamsu Yusuf dan Nani Sugandi, 2015: 59).

Vol.15 No.7 Februari 2021 
Salah satu aspek penting dalam perkembangan anak usia dini adalah aspek kemampuan motorik kasar. Kemampuan motorik kasar adalah kemampuan yang berkaitan erat dengan koordinasi, keseimbangan, kekuatan, otot-otot besar. Kemampuan motorik kasar diperlukan oleh anak dalam rangka melakukan kegiatan-kegiatan di luar ruangan yang membutuhkan kemampuan otot besar.

Dengan meningkatkan kemampuan fisik motorik anak maka akan berpengaruh juga pada perilaku anak sehari-hari. Kegiatan yang dapat dilakukan oleh seorang pendidik untuk meningkatkan fisik motorik anak yaitu dengan memberikan berbagai macam bentuk permainan baik dilakukan di dalam kelas maupun di luar kelas. Karena dunia anak itu pada dasarnya adalah dunia bermain, anak bermain sambil belajar atau belajar seraya bermain. Bermain merupakan suatu kegiatan yang menyenangkan dan spontan sehingga hal ini dapat memberikan rasa aman secara psikologis pada anak.

Menurut Sumantri (2005: 271), motorik kasar merupakan keterampilan yang bercirikan gerak yang melibatkan sekelompok otot-otot besar sebagai dasar utama geraknya. Santrock (2009: 209) menyatakan bahwa keterampilan motorik kasar (gross motor skill) merupakan keterampilan yang melibatkan aktivitas otot besar seperti tangan seorang anak untuk bergerak dan kaki untuk berjalan, sedangkan menurut Decaprio (2013: 18) juga berpendapat bahwa motorik kasar adalah gerakan tubuh yang menggunakan otot-otot besar atau sebagian otot yang ada dalam tubuh maupun seluruh anggota tubuh yang dipengaruhi oleh kematangan diri.

Sedangkan menurut Samsudin (2008: 9), motorik kasar adalah kemampuan anak TK beraktivitas dengan menggunakan otot-otot besar. kemampuan menggunakan otot-otot ini bagi anak TK tergolong pada kemampuan gerak dasar dibagi menjadi tiga kategori, yaitu: lokomotor, non lokomotor, dan manipulatif. Menurut Beaty di kutip oleh Muhammad Fadillah dan Lilif Khorida, (2013: 59) Kemampuan motorik kasar seorang anak dapat dilihat melalui empat aspek, yaitu a) berjalan atau walking, Vol.15 No.7 Februari 2021 dengan indikator turun naik tangga dengan menggunakan ke dua kaki, berjalan pada garis lurus dan berdiri satu kaki ; b) berlari atau running, dengan indikator menunjukkan kekuatan dan kecepatan berlari, berbelok ke kanan-kiri tanpa kesulitan dan mampu berhenti dengan mudah; c) melompat atau jumping, dengan indikator mampu melompat ke depan, ke belakang, dan ke samping; dan d) memanjat atau climbing, dengan indikator memanjat naik- turun tangga dan memanjat pepohonan.

Berdasarkan hasil observasi yang telah di lakukan di TK Kartika VI-15 Biak Kabupaten Biak Numfor, peneliti tertarik untuk meningkatkan motorik kasar anak. Berdasarkan wawancara serta penelitian langsung yang dilakukan di TK tersebut kegiatan yang dilakukan di luar ruangan merupakan kegiatan yang jarang dilakukan oleh murid di TK tersebut. Dilihat dari 16 orang anak di kelompok B, dan belum mengalami peningkatan motorik kasar sebesar $56,25 \%$.

Bertitik tolak pada paparan permasalahan tersebut, maka perlu dirancang suatu permainan yang menarik bagi anak untuk meningkatkan motorik kasar anak. Peneliti merasa perlu untuk menggunakan sebuah permainan yaitu permainan bola estafet.

Permainan adalah medium yang sangat tepat untuk perkembangan sosial dan moral anak, permainan tidak sepenuhnya menyenangkan, anak-anak harus diajarkan untuk selalu teribat sepenuhnya dalam permainan. Jika dalam suatu permainan anak harus keluar atau tereliminasi karena kurang terampil maka permainan tersebut menjadi pengalaman yang tidak menyenangkan baginya. Permainan harus sederhana dan mudah diajarkan serta membutuhkan gerak dasar lokomotor dan menyediakan sarana yang menyenangkan. Dalam permainan yang baik ada beberapa aspek/ranah yang dicapai seperti ranah psikomotor, ranah kognitif dan ranah afektif.

Permainan yang sangat bermanfaat untuk semua aspek perkembangan anak adalah permainan yang dapat mengaktifkan semua anak bersamasama. Permainan ini harus dapat mendorong anak

http://ejurnal.binawakya.or.id/index.php/MBI 
mengeluarkan usahanya secara maksimal ketika sedang terlibat dalam permainan.

Permainan bola estafet atau bola beranting adalah permainan yang dilaksanakan oleh beberapa orang anak secara berkelompok. Aturan permainan bola estafet disini sebenarnya sama dengan permainan lari estafet yang menggunakan tongkat, tetapi pada permainan bola estafet menggunakan bola-bola kecil sebagai media/alatnya, ini dilakukan oleh peneliti dengan alasan faktor keamanan. Pada permainan bola estafet, pemain pertama akan memindahkan bola sambil berlari cepat ke pemain kedua dan selanjutnya pemain kedua akan berlari cepat membawa bola ke pemain ke tiga dan begitu seterunya sampai pada pemain terakhir akan membawa bola di garis finish.

Bambang Sujiono (2008: 1.19-1.24) menyebutkan bahwa bermain estafet juga memiliki tujuan yang baik untuk anak usia dini antara lain, yaitu: (1) melatih ketangkasan, (2) melatih meningkatkan koordinasi, (3) melatih kecepatan, (4) melatih sikap kerja sama, (5) melatih kelincahan. Dengan demikian bermain estafet apabila dikembangkan sangat memiliki banyak manfaat untuk anak-anak baik dalam menjalankan aktivitas belajar dalam bermain maupun dalam melakukan kegiatan sehari-hari dapat berjalan secara optimal.

\section{METODE PENELITIAN}

Jenis penelitian yang digunakan adalah Penelitian Tindakan Kelas (PTK). Penelitian ini dilaksanakan pada Kelompok B TK Kartika VI15 Biak Kabupaten Biak Numfor. Penelitian dilaksanakan pada semester genap tahun ajaran 2018/2019.

Subjek dalam penelitian ini adalah anak kelompok B TK Kartika VI-15 Kabupaten Biak Numfor yang berjumlah 16 orang anak yang terdiri dari 8 orang anak laki-laki dan 8 orang anak perempuan. Adapun faktor-faktor yang diteliti dan diamati dalam penelitian ini adalah: a) faktor anak didik, mengamati aktivitas anak dalam meningkatkan kemampuan motorik kasar anak melalui permainan bola estafet, dan b) faktor guru, mengamati dan memperhatikan http://ejurnal.binawakya.or.id/index.php/MBI

\section{Open Journal Systems}

segala aktivitas guru yang mempersiapkan dan melaksanakan kegiatan pembelajaran dalam meningkatkan kemampuan motorik kasar anak melalui permainan bola estafet.

Data yang diperoleh dari penelitian ini adalah data kualitatif dan data kuantitatif. Data kualitatif digunakan untuk menghimpun data tentang pelaksanaan proses pembelajaran yang dilaksanakan oleh guru dan anak. Data kualitatif diperoleh melalui lembar observasi. Sedangkan data kuantitatif menghimpun data tentang peningkatan kemampuan motorik kasar anak melalui permainan bola estafet yang diperoleh melalui lembar instrumen/evaluasi yang dilakukan pada setiap pertemuan dan diakhir siklus tindakan.

Untuk menentukan keberhasilan dan keefektifan dalam penelitian ini, maka dirumuskan indikator kinerjanya yang digunakan sebagai acuan keberhasilan. Adapun indikator kinerjanya yaitu $85 \%$.

\section{Teknik Analisis Data}

1. Keberhasilan anak didik secara individual, dengan rumus:

Persentasi keberhasilan individual $=\frac{\text { Skor perolehan }}{\text { skor maksimal }}$ Berdasarkan rumus tersebut, maka keberhasilan secara individual dapat dikelompokkan sebagai berikut:

Tabel 1. Kategori Keberhasilan Secara Individual

\begin{tabular}{|c|l|c|}
\hline Nilai & \multicolumn{1}{|c|}{ Kategori } & keterangan \\
\hline $3,50-4,00$ & $\begin{array}{l}\text { Berkembang } \\
\text { sangat baik(BSB) }\end{array}$ & $* * * *$ \\
\hline $2,50-3,49$ & $\begin{array}{l}\text { Berkembang } \\
\text { sesuai } \\
\text { harapan(BSH) }\end{array}$ & $* * *$ \\
\hline $1,50-2,49$ & $\begin{array}{l}\text { Mulai } \\
\text { berkembang(MB) }\end{array}$ & $* *$ \\
\hline $0,01-1,49$ & $\begin{array}{l}\text { Belum } \\
\text { berkembang(BB) }\end{array}$ & $*$ \\
\hline
\end{tabular}

(Depdiknas, 2004: 26)

2. Untuk mengetahui presentasi keberhasilan anak didik secara klasikal, dengan rumus sebagai berikut:

Vol.15 No.7 Februari 2021 


\section{Jumlah anak yang memperoleh nilai}

Persentasi keberhasilan individual $=\frac{B S B \text { dan } B S H}{\text { Jumlah } a n a k} \times 100 \%$

Berdasarkan rumus tersebut, maka keberhasilan secara klasikal dapat dikelompokkan sebagai berikut:

Tabel 2. Kategori keberhasilan Secara Klasikal

\begin{tabular}{|c|l|c|}
\hline Persentase & \multicolumn{1}{|c|}{ Kategori } & $\begin{array}{c}\text { Simbol } \\
\text { Bintang }\end{array}$ \\
\hline $95 \%-100 \%$ & $\begin{array}{l}\text { Berkembang sangat } \\
\text { baik(BSB) }\end{array}$ & $* * * *$ \\
\hline $85 \%-94 \%$ & $\begin{array}{l}\text { Berkembang sesuai } \\
\text { harapan(BSH) }\end{array}$ & $* * *$ \\
\hline $75 \%-84 \%$ & $\begin{array}{l}\text { Mulai } \\
\text { berkembang(MB) }\end{array}$ & $* *$ \\
\hline$<75 \%$ & $\begin{array}{l}\text { Belum } \\
\text { berkembang(BB) }\end{array}$ & $*$ \\
\hline
\end{tabular}

(Depdiknas, 2004: 26)

\section{HASIL DAN PEMBAHASAN}

Sebelum kegiatan ini dilakukan, peneliti terlebih dahulu melakukan pertemuan dengan Kepala Sekolah TK Kartika VI-15 Kabupaten Biak Numfor pada tanggal 28 Januari 2019. Pertemuan ini bermaksud untuk menyampaikan tujuan dari peneliti yaitu mengadakan penelitian di TK Kartika VI-15 Kabupaten Biak Numfor. Dan selanjutnya kepala Sekolah mengarahkan langsung peneliti untuk berdiskusi dengan guru kelompok B berkaitan dengan kegiatan yang akan dilakukan peneliti dalam meningkatkan motorik kasar melalui permainan bola estafet. Berdasarkan hasil observasi dan dilanjutkan dengan wawancara dengan guru kelompok B bahwa pembelajaran yang dilakukan di luar kelas merupakan kegiatan yang jarang dilakukan oleh anak, sehingga peneliti tertarik untuk melakukan penelitian di TK Kartika VI-15 Biak Kabupaten Biak Numfor.

Berdasarkan permasalahan yang terjadi maka peneliti berusaha membuat suatu kegiatan yang menyenangkan bagi anak untuk meningkatkan kemampuan motorik kasar melalui

Vol.15 No.7 Februari 2021 permainan bola estafet di kelompok B TK Kartika VI-15 Kabupaten Biak Numfor.

Penelitian ini dilakukan dalam dua siklus dimana setiap siklus terdiri dari empat kali pertemuan. Pada siklus I terdiri atas perencanaan, pelaksanaan tindakan, pengamatan, dan refleksi. Masing-masing dapat diuraikan sebagai berikut:

\section{Tindakan Siklus I}

a. Perencanaan

Setelah disepakati untuk melakukan kegiatan pembelajaran motorik kasar melalui permainan bola estafet maka kegiatan selanjutnya peneliti melakukan beberapa hal yaitu sebagai berikut: (a) menyiapkan rencana pelaksanaan mingguan (RPPM) dan rencana pelaksanaan pembelajaran harian (RPPH) dengan tema binatang sub tema macam-macam binatang, (b) menyiapkan media pembelajaran berupa bola plastik berukuran sedang, (c) membuat lembar observasi aktivitas guru dan anak selama proses pembelajaran sebagai acuan untuk melihat tentang proses pembelajaran sesuai dengan yang direncanakan.

b. Pelaksanaan tindakan

Tindakan pada siklus I, peneliti melaksanakan tindakan pembelajaran sesuai dengan Rencana Pelaksanaan Pembelajaran Harian (RPPH) yang telah dipersiapkan terlebih dahulu dengan tema binatang sub tema macam-macam binatang. Untuk pelaksanaan tindakan setiap pertemuan akan dijabarkan sebagai berikut:

1) Pertemuan $I$

Pelakasanaan tindakan siklus I pertemuan I dilaksanakan pada hari Senin 4 Februari 2019 dengan tema binatang sub tema macam-macam binatang darat (ayam). Pada pelaksanaan tindakan ini, peneliti melaksanakan pembelajaran pada RPPH siklus I, yaitu sebelum kegiatan pembelajaran dimulai peneliti atau guru menyambut kedatangan setiap anak dengan apel pagi yang dipimpin oleh seorang guru yang mendapat piket. Pada saat berbaris anak-anak didik diatur secara rapi setelah itu guru tidak lupa

http://ejurnal.binawakya.or.id/index.php/MBI 
mengajak anak untuk bernyanyi "lonceng berbunyi" setelah menyanyi guru menanyakan kepada anak tentang kondisi anak pada hari itu, serta guru menanyakan tentang hari, tanggal, bulan, tahun. Setelah anak berbaris guru langsung mempersilahkan anak untuk masuk kelas masing-masing.

Pada kegiatan inti di siklus I pertemuan I dalam meningkatkan kemampuan motorik kasar anak, terlebih dahulu peneliti menjelaskan tema dan sub tema serta permainan bola esatafet kepada anak, setelah menjelaskan tema dan sub tema peneliti langsung memberikan contoh cara melakukan permainan bola estafet. terdapat 4 orang anak yang melakukan posisi start dengan benar, 7 orang anak yang dapat memegang erat bola agar tidak terlepas, 9 orang anak yang dapat menjaga keseimbangan tubuh pada saat berlari, dan 5 orang anak yang melakukan permainan bola estafet sesuai dengan aturan yang telah ditetapkan.

Kegiatan akhir yaitu peneliti melakukan tanya jawab kepada anak mengenai kegiatan yang telah dilakukan. Selanjutnya peneliti mempersiapkan anak untuk pulang serta membimbing anak bernyanyi bersama, berdoa,dan salam.

2) Pertemuan II

Pelaksanaan tindakan siklus I pertemuan II dilaksanakan pada hari selasa 5 Februari 2019 dengan tema binatang sub tema macammacam binatang darat (sapi). pada pelaksanaan tindakan siklus I pertemuan II, peneliti melaksanakan pembelajaran pada Rencana Pelaksanaan Pembelajaran Harian (RPPH) siklus I, yaitu sebelum kegiatan pembelajaran dimulai, guru atau peneliti menyambut setiap kedatangan anak untuk apel pagi. Sebelum kegiatan pembelajaran dimulai terlebih dahulu anak-anak apel pagi di depan kelas yang dipimpin oleh seorang guru piket. Setelah barisan anak didik rapi, anak-anak dipersilahkan masuk kedalam kelas, akan tetapi anak-anak kelompok B langsung diarahkan menuju lapangan untuk melakukan kegiatan.

http://ejurnal.binawakya.or.id/index.php/MBI
Pada kegiatan inti siklus I pertemuan II, peneliti melakukan review tentang pelajaran yang telah dilakukan sebelumnya yaitu pemahaman anak tentang permainan bola estafet. Selanjutnya peneliti langsung membagi anak ke dalam beberapa kelompok atau regu. Pada saat melakukan pembagian kelompok ada beberapa anak yang susah diatur akan tetapi hal tersebut dapat diatasi. Selanjutnya setelah anak-anak di bagi dalam beberapa kelompok atau regu kegiatan langsung berjalan dengan lancar. Pada siklus I pertemuan II ada 10 orang anak yang memegang erat bola agar tidak terlepas, sedangkan anak yang melakukan posisi start dengan benar sebanyak 6 orang anak, serta anak yang menjaga keseimbangan tubuh pada saat berlari sebanyak 13 orang anak, dan yang melakukan permainan bola estafet sesuai dengan aturan yang telah ditetapkan sebanyak 5 orang anak.

Setelah kegiatan selesai peneliti mempersilahkan anak untuk istirahat, selanjutnya anak masuk dalam ruangan untuk bersiap pulang, sebelum pulang peneliti membimbing anak untuk membaca doa pulang, memberi salam dan pulang.

3) Pertemuan III

Pelaksanaan tindakan siklus I pertemuan III dilaksanakan pada hari rabu 6 Februari 2019 dengan tema binatang dan sub tema macam-macam binatang darat (kambing). Pada pelaksanaan tindakan ini, peneliti melaksanakan pembelajaran pada RPPH siklus I, yaitu sebelum kegiatan pembelajaran dimulai, guru dan peneliti menyambut kedatangan anak ke sekolah kemudian kegiatan selanjutnya yaitu apel pagi. Anak-anak berbaris diluar halaman kelas yang dipimpin oleh salah satu guru yang mendapat piket. Setelah barisan anak didik rapi, guru langsung mempersilahkan anak untuk masuk kelas masing-masing akan tetapi anak kelompok B langsung diarahkan menuju lapangan untuk melaksanakan kegiatan seperti yang mereka lakukan sebelumnya.

Vol.15 No.7 Februari 2021 
Pada kegiatan inti di siklus I pertemuan III peneliti melakukan review yakni menanyakan kembali kepada anak mengenai permainan bola estafet yang sudah mereka lakukan sebelumnya. Selanjutnya peneliti memberikan contoh permainan bola estafet tentang bagaimana melakukan posisi start, apa-apa saja aturan permainan yang ada. Setelah menjelaskan anak-anak langsung melakukan kegiatan. Anak yang menjaga keseimbangan tubuh pada saat berlari sebanyak 15 orang anak, sedangkan anak yang melakukan posisi star dengan benar sebanyak 8 orang anak, dan anak yang memegang erat bola agar tidak terlepas sebanyak 11 orang anak, serta anak yang melakukan permainan bola estafet sesuai dengan aturan yang telah ditetapkan yaitu 7 orang anak.

Selanjutnya setelah anak-anak melakukan kegiatan langsung saja peneliti mengarahkan anak-anak untuk makan dan mempersilahkan juga anak untuk bermain atau istirahat. Selanjutnya anak di masukkan di dalam ruangan untuk bersiap pulang, sebelum pulang guru menyimpulkan kegiatan yang telah di lakukan anak. Setelah peneliti menyimpulkan kegiatan langsung saja peneliti membimbing anak doa pulang, beserta mengucapkan salam.

4) Pertemuan IV

Pelaksanaan tindakan siklus I pertemuan IV, dilaksanakan pada hari kamis 7 Februari 2019 dengan menggunakan tema binatang dan sub tema macam-macam binatang darat (kelinci) Pada pelaksanaan tindakan ini, peneliti melaksanakan pembelajaran pada RPPH siklus I. dimulai peneliti atau guru menyambut kedatangan setiap anak, kemudian apel pagi yang dipimpin oleh salah satu guru yang mendapat piket. Pada saat berbaris anakanak didik diatur secara rapi kemudian guru tidak lupa menanyakan kondisi anak pada hari itu serta menanyakan hari, tanggal, bulan, serta tahun.

Pada kegiatan inti di siklus I pertemuan IV seperti biasa peneliti mengarahkan anak langsung menuju lapangan untuk melakukan

Vol.15 No.7 Februari 2021 kegiatan permainan fisik. Sebelum Peneliti membagi anak ke dalam beberapa kelompok, terlebih dahulu peneliti menanyakan kabar anak serta kagiatan yang telah dilakukan kemarin. Kegiatan selanjutnya akan di laksanakan yaitu melakukan kegiatan permainan bola estafet. terdapat 8 orang anak yang dapat melakukan posisi start dengan benar, sedangkan anak yang memegang erat bola agar tidak terlepas sebanyak 11 orang anak, dan anak yang melakukan permainan bola estafet sesuai dengan aturan yang ditetapkan sebanyak 7 orang anak, dan 16 orang anak yang menjaga keseimbangan tubuh pada saat berlari.

Setelah kegiatan selesai anak langsung dipersilahkan untuk istirahat. Kemudian peneliti melakukan tanya jawab kepada anak mengenai kegiatan yang telah dilakukan. Setelah itu peneliti membimbing anak membaca surah-surah pendek, membaca doa pulang, menyanyi, salam dan pulang.

5) Pengamatan

Peneliti yang dibantu oleh observer untuk mengamati pelaksanaan siklus I pertemuan I sampai pertemuan IV mulai dari awal kegiatan sampai akhir kegiatan pembelajaran dalam meningkatkan kemampuan motorik kasar melalui permainan bola estafet di mana setiap pertemuan menggunakan lembar observasi tentang aktivitas mengajar guru serta anak.

\section{Hasil Pengamatan Aktivitas Mengajar Guru Pada Siklus I}

Sebelum kegiatan pembelajaran dimulai guru menanyakan kabar anak, kemudian menyiapkan anak untuk belajar, mengucapkan salam, membimbing anak untuk berdoa sebelum belajar.

Hasil observasi guru sesuai dengan pedoman lembar observasi sebanyak 14 aspek yang harus dicapai oleh guru. Pada siklus 1 skor yang dicapai oleh guru dari 14 aspek hanya 10 aspek atau $71,43 \%$ adapun aspek yang tercapai diantaranya sebagai berikut: (1) guru menyiapkan media dalam proses pembelajaran, (2) guru mengucapkan salam, (3) guru menyampaikan http://ejurnal.binawakya.or.id/index.php/MBI 
tugas yang akan dilakukan, (4) guru menyampaikan tema dan sub tema, (5) guru memberikan bimbingan kepada anak dalam melakukan permainan, (6) guru memperlihatkan dan menjelaskan media yang akan digunakan, (7) guru memberikan contoh kepada anak dalam melakukan permainan bola estafet, (8) guru mengadakan tanya jawab mengenai kegiatan awal sampai akhir kegiatan, (9) guru menyimpulkan kegiatan yang telah dilakukan, (10) guru membimbing anak untuk pulang.

Untuk lebih jelasnya dapat dilihat dari histogram berikut:

\section{Gambar 1. Histogram Hasil Pengamatan} Aktivitas Mengajar Guru Siklus I

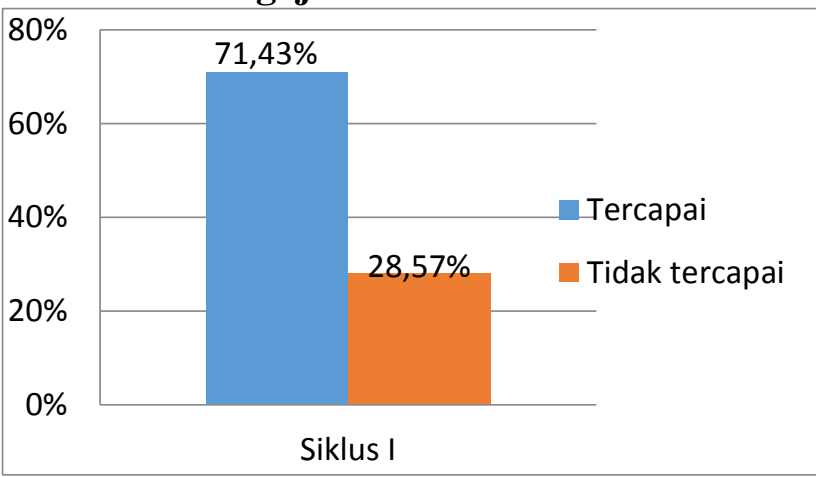

Berdasarkan diagram 1 dapat diketahui bahwa aktivitas mengajar guru pada siklus 1 baru mencapai sekitar $71,43 \%$ sedangkan aktivitas mengajar guru yang tidak tercapai yaitu sekitar $28,57 \%$. Dengan demikian aktivitas mengajar guru pada siklus 1 belum maksimal.

Hasil Observasi Aktivitas Belajar Anak pada siklus I

Observasi yang dilakukan pada aktivitas belajar anak pada siklus I yang diamati observer menggunakan lembar observasi aktivitas belajar anak yang terdiri dari 14 aspek. Pada siklus I baru sekitar 9 aspek saja yang tercapai atau sekitar 64,29\% diantaranya sebagai berikut: (1) anak menjawab salam (2) anak berbaris di depan kelas, (3) anak berdoa sebelum belajar (4) anak siap untuk belajar(5) anak memperhatikan guru menyampaikan kegiatan pembelajaran, (6) anak memperhatikan media yang akan digunakan, (7) anak melakukan permainan bola estafet setelah dicontohkan oleh guru, (8) anak memperhatikan guru memberikan contoh bermain bola estafet, http://ejurnal.binawakya.or.id/index.php/MBI
(9) anak mengikuti arahan dari guru untuk pembagian kelompok.

Untuk lebih jelasnya dapat dilihat pada histogram berikut:

Gambar 2. Histogram Hasil Observasi Aktivitas Belajar Anak Siklus I

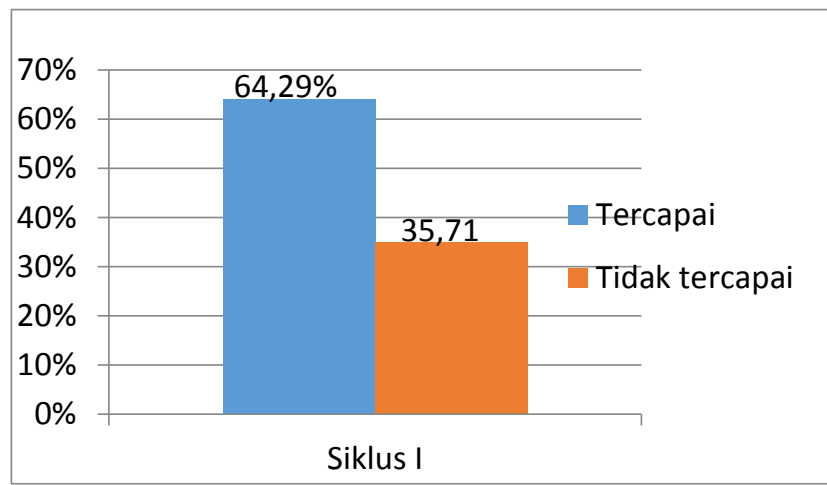

Berdasarkan diagram 2 dapat diketahui bahwa aktivitas belajar anak pada siklus I baru mencapai sekitar $64,29 \%$, sedangkan aktivitas belajar anak yang tidak tercapai adalah $35,71 \%$. Dengan demikian aktivitas belajar anak pada siklus I belum maksimal.

Peneliti yang bekerjasama dengan guru kelompok B melakukan evaluasi pada akhir siklus. Evaluasi dilakukan untuk mengetahui perkembangan kemampuan motorik kasar anak melalui permainan bola estafet (bola ranting). Evaluasi dilakukan untuk megetahui sampai sejauh mana kemampuan motorik kasar anak setelah dilakukannya tindakan pada siklus I. Pencapaian keberhasilan anak dikelompokkan dalam empat kategori yaitu Berkembang Sangat Baik (BSB), Berkembang Sesuai Harapan (BSH), Mulai Berkembang (MB), serta Belum Berkembang (BB).

Tabel 3. Nilai Klasikal Motorik Kasar Melalui Permainan Bola Estafet Siklus I

\begin{tabular}{|lr|c|c|}
\hline \multicolumn{2}{|c|}{ Nilai } & f & \% \\
\hline $\begin{array}{l}\text { Berkembang } \\
\text { Baik (BSB) }\end{array}$ Dengat & & $\mathbf{0}$ \\
Skor (3,50-4,00) & $\mathbf{0}$ & \\
\hline $\begin{array}{l}\text { Berkembang } \\
\text { Harapan }\end{array}$ & $\begin{array}{l}\text { Sesuai } \\
\text { (BSH) }\end{array}$ & $\mathbf{1 1}$ & $\mathbf{6 8 , 7 5 \%}$ \\
$\begin{array}{l}\text { Dengan Skor } \\
\text { 3,49) }\end{array}$ & & \\
\hline
\end{tabular}

Vol.15 No.7 Februari 2021

\section{Open Journal Systems}




\begin{tabular}{|c|c|c|}
\hline $\begin{array}{l}\text { Mulai Berkembang } \\
(\mathrm{MB}) \text { Dengan Skor } \\
(1,50-2,49)\end{array}$ & 5 & $31,25 \%$ \\
\hline $\begin{array}{l}\text { Belum Berkembang } \\
\text { (BB) Dengan Skor } \\
(1,00-1,49)\end{array}$ & $\mathbf{0}$ & $\mathbf{0}$ \\
\hline Jumlah & 16 & $100 \%$ \\
\hline
\end{tabular}

(sumber: diolah dari data penelitian 2019)

Berdasarkan hasil yang ada pada tabel 4.1 dapat dilihat bahwa secara klasikal, meningkatkan kemampuan motorik kasar melalui permainan bola estafet (bola ranting) di kelompok B TK Kartika VI-15 Kabupaten Biak Numfor pada tahap penilaian siklus I, tidak ada anak yang memperoleh nilai bintang (****) atau Berkembang Sangat Baik (BSB), anak yang memperoleh nilai bintang $(* * *)$ atau Berkembang Sesuai Harapan sebanyak (BSH) sebanyak 11 orang anak atau 68,75\%, sedangkan anak yang memperoleh nilai bintang $(* *)$ atau Mulai Berkembang (MB) sebanyak 5 orang anak atau sekitar $31,25 \%$, dan tidak ada anak yang memperoleh nilai bintang (*) atau Belum Berkembang (BB). Berdasarkan hasil evaluasi tersebut, sebagian besar anak sudah dapat melaksanakan kegiatan dengan baik namun belum mencapai indikator kinerja yaitu $85 \%$.

d. Refleksi

Berdasarkan hasil yang telah diperoleh pada pelaksanaan kegiatan untuk siklus I, dapat terlihat bahwa kegiatan penelitian yang dilaksanakan dalam meningkatkan kemampuan motorik kasar melalui permaianan bola estafet di kelompok B TK Kartika VI-15 Biak Kabupaten Biak Numfor belum terselesaikan sepenuhnya. Sedangkan indikator kinerja yang ditetapkan minimal $85 \%$ anak yang memperoleh nilai bintang (****) atau Berkembang Sangat Baik serta bintang $(* * *)$ atau Berkembang Sesuai Harapan, hal tersebut dikarenakan masih ada sebagian kendala-kendala yang belum terselesaikan pada pelaksanaan tindakan siklus I, sehingga harus membuat persiapan dan perencanaan yang lebih matang lagi agar pelaksanaan tindakan siklus II lebih meningkat di banding siklus I. Berdasarkan hasil observasi, ada beberapa hal yang perlu di perbaiki untuk pelaksanaan tindakan siklus II yaitu kurangnya kemampuan peneliti dalam mengelola kelas, guru harus menyampaikan tujuan pembelajaran setiap kali pertemuan, guru harus memberikan motivasi, penguatan, serta penghargaan kepada anak agar anak lebih semangat lagi dalam melaksanakan kegiatan, guru juga harus lebih semangat untuk menceritakan kepada anak hal-hal yang menarik mengenai kegiatan yang akan dilakukan agar hasil belajar anak didik di siklus II diharapkan dapat mencapai indikator kinerja $85 \%$.

\section{Tindakan Siklus II}

Penelitian ini dilakukan sebanyak dua siklus dimana dalam satu siklus terdiri dari empat kali pertemuan. Pada siklus II terdiri atas perencanaan, pelaksanaan tindakan, pengamatan, dan refleksi. Masing-masing dapat diuraikan sebagai berikut:

a. Perencanaan

Setelah disepakati untuk melakukan kegiatan pembelajaran motorik kasar melalui permainan bola estafet (bola ranting) maka kegiatan selanjutnya peneliti melakukan beberapa hal yaitu sebagai berikut: (a) menyiapkan rencana pelaksanaan mingguan (RPPM) dan rencana pelaksanaan pembelajaran harian (RPPH) dengan tema binatang sub tema macam-macam binatang, (b) menyiapkan media pembelajaran berupa bola plastik berukuran sedang, (c) membuat lembar observasi aktivitas guru dan anak selama proses pembelajaran sebagai acuan untuk melihat tentang proses pembelajaran sesuai dengan yang direncanakan.

b. Pelaksanaan tindakan

1.) Pertemuan $I$

Pelakasanaan tindakan siklus II pertemuan I dilaksanakan pada hari senin 11 Februari 2019 dengan tema binatang sub tema macam-macam binatang (kupu-kupu) Pada pelaksanaan tindakan ini, peneliti melaksanakan pembelajaran yaitu sebelum kegiatan pembelajaran dimulai peneliti atau http://ejurnal.binawakya.or.id/index.php/MBI 
guru menyambut kedatangan setiap anak, kemudian apel pagi yang dipimpin oleh seorang guru yang piket. Pada saat berbaris anak-anak didik diatur secara rapi setelah itu guru tidak lupa mengajak anak untuk bernyanyi "lonceng berbunyi" setelah menyanyi guru menanyakan kepada anak tentang kondisi anak pada hari itu, tidak lupa juga guru menanyakan tentang hari, tanggal, bulan, serta tahun. Setelah anak berbaris guru langsung mempersilahkan anak untuk masuk kelas masing-masing akan tetapi anak kelompok B diarahkan langsung menuju lapangan untuk melakukan kegiatan dalam hal meningkatkan kemampuan motorik kasar.

Pada kegiatan inti di siklus II pertemuan I dalam meningkatkan kemampuan motorik kasar anak, peneliti menjelaskan kembali materi tentang permainan bola estafet serta macam-macam binatang (kupu-kupu) dengan memperlihatkan gambar kupu-kupu yang ada pada bola peneliti langsung menjelaskan kembali kepada anak anak tentang teknik permainan bola estafet. setelah itu, peneliti mengarahkan anak-anak untuk melakukan kegiatan tersebut. Kemudian anak-anak mengambil posisi, ada yang mendapat posisi pertama, ada juga anak yang mendapat posisi ke dua, dan seterusnya. Jumlah anak yang melakukan permainan bola estafet sesuai dengan aturan yang telah ditetapkan sebanyak 8 orang anak, dan anak yang melakukan posisi start dengan benar sebanyak 8 orang anak, dan 11 orang anak yang memegang erat bola agar tidak terlepas, dan 16 orang anak yang menjaga keseimbangan tubuh pada saat berlari.

Kegiatan akhir yaitu peneliti menyimpulkan kegiatan yang telah dilakukan hari ini serta peneliti mengadakan tanya jawab mengenai kegiatan dari awal sampai akhir kegiatan. Selanjutnya peneliti memberikan motivasi kepada anak. Serta menyiapkan anak untuk pulang dengan bernyanyi bersama serta berdoa dan pulang.
2) Pertemuan II

Pelaksanaan tindakan siklus II pertemuan II dilaksanakan pada hari selasa 12 Februari 2019 dengan tema binatang sub tema macammacam binatang (lalat). Pada pelaksanaan tindakan siklus II pertemuan II, peneliti melaksanakan pembelajaran seperti biasa yaitu sebelum kegiatan pembelajaran dimulai, peneliti telah menyiapkan media pembelajaran yang akan digunakan dalam pembelajaran tentang motorik kasar melalui permainan bola estafet. Sebelum kegiatan pembelajaran dimulai terlebih dahulu anak-anak apel pagi di depan kelas yang dipimpin oleh seorang guru piket. Setelah barisan anak didik rapi, anakanak dipersilahkan masuk kedalam kelas akan tetapi anak kelompok B lagi-lagi diarahkan untuk menuju lapangan.

Pada kegiatan inti siklus II pertemuan II, guru melakukan review tentang pelajaran yang telah dilakukan sebelumnya yaitu pemahaman anak tentang cara melakukan permainan bola estafet. peneliti kembali memberikan contoh kepada anak dalam melakukan permaian bola estafet setelah itu peneliti membagi anak-anak kedalam beberapa kelompok untuk melaksanakan kegiatan. Dimana jumlah anak yang melakukan posisi start dengan benar sebanyak 10 orang anak, dan anak yang memegang erat bola agar tidak terlepas sebanyak 14 orang anak, dan 16 orang anak yang menjaga keseimbangan tubuh pada saat berlari, serta 10 anak yang melakukan permainan bola estafet sesuai dengan aturan yang telah ditentukan.

Kegiatan akhir yaitu anak masuk dalam ruangan untuk bersiap pulang, sebelum pulang guru selalu memberikan motivasi-motivasi kepada anak serta menyimpulkan kegiatan dari awal sampai akhir kegiatan. Guru membimbing anak untuk membaca doa pulang, dan bernyanyi, serta salam.

3) Pertemuan III

Pelaksanaan tindakan siklus II pertemuan III dilaksanakan pada hari rabu 13 Februari 2019 dengan tema binatang dan sub tema macam-macam binatang (nyamuk). Pada

Vol.15 No.7 Februari 2021 
pelaksanaan tindakan ini, guru melaksanakan pembelajaranyaitu sebelum kegiatan pembelajaran dimulai, guru telah menyiapkan media pembelajaran terlebih dahulu berupa bola plastik ukuran sedang. Guru dan peneliti menyambut kedatangan anak ke sekolah kemudian kegiatan selanjutnya yaitu apel pagi. Anak-anak berbaris diluar halaman kelas yang dipimpin oleh seorang guru piket. Setelah barisan anak didik rapi, lagi dan lagi anak kelompok A dipersilahkan untuk masuk kelas sedangkan anak kelompok B diarahkan langsung menuju tempat kegiatan untuk melaksanakan pembelajaran seperti biasanya.

Pada kegiatan inti di siklus II pertemuan III seperti sebelumnya peneliti melakukan review yakni menanyakan kepada anak mengenai permainan bola estafet. Selanjutnya peneliti langsung membagi anak-anak kedalam beberapa kelompok dan anak-anak bergegas untuk mengambil posisi masingmasing ada yang mendapat posisi pertama, dan ada yang mendapat posisi ke dua dan seterusnya. Jumlah anak yang melakukan permainan bola estafet dengan benar sebanyak 12 orang anak, dan 14 orang anak yang memegang erat bola agar tidak terlepas, dan 16 orang anak yang dapat menjaga keseimbangan tubuh pada saat berlari, 12 orang anak yang melakukan permainan bola estafet sesuai aturan yang telah ditetapkan.

Kegiatan akhir yaitu anak dimasukkan di dalam ruangan untuk bersiap pulang, sebelum pulang peneliti memberikan motivasi kepada anak agar lebih semangat lagi dalam melakukan kegiatan tersebut. Peneliti juga menyimpulkan kegiatan yang telah di lakukan anak kemudian peneliti mengadakan tanya jawab dengan anak mengenai kegiatan dari awal sampai akhir. peneliti membimbing anak menyanyi, membaca doa pulang, serta mengucapkan salam.

4) Pertemuan IV

Pelaksanaan tindakan siklus II pertemuan IV, dilaksanakan pada hari kamis 14 Februari 2019 dengan menggunakan tema binatang dan sub tema macam-macam binatang (belalang).

Vol.15 No.7 Februari 2021
Pada pelaksanaan tindakan ini, guru melaksanakan pembelajaran yaitu peneliti atau guru menyambut kedatangan setiap anak kemudian apel pagi yang dipimpin oleh seorang guru piket. Pada saat berbaris anakanak didik diatur secara rapi kemudian guru menanyakan kondisi anak pada hari itu serta menanyakan hari, tanggal, bulan, serta tahun kemudian anak di ajak bernyanyi.

Pada kegiatan inti di siklus II pertemuan IV peneliti langsung mengarahkan anak untuk menuju lapangan untuk melakukan kegiatan permainan bola estafet. Peneliti mengarahkan anak untuk melakukan permainan bola estafet. jumlah anak yang melakukan posisi start dengan benar sebanyak 13 orang anak, dan anak yang memegang erat bola agar tidak terlepas yaitu 14 orang anak, serta 16 orang anak yang menjaga keseimbangan tubuh pada saat berlari, dan yang melakukan permainan bola estafet sesuai dengan aturan yang telah ditetapkan sebanyak 12 orang anak.

Kegiatan akhir yaitu peneliti mengadakan tanya jawab kembali kepada anak mengenai kegiatan yang sudah dilakukan. Setelah itu peneliti membimbing anak membaca doa pulang, menyanyi, salam dan pulang.

c. Pengamatan

Peneliti yang dibantu oleh observer untuk mengamati pelaksanaan siklus II pertemuan I sampai pertemuan IV mulai dari awal kegiatan sampai akhir kegiatan pembelajaran dalam meningkatkan kemampuan motorik kasar melalui permainan bola estafet di mana setiap pertemuan menggunakan lembar observasi tentang aktivitas mengajar guru serta anak.

\section{Hasil Pengamatan Aktivitas Mengajar Guru Pada Siklus II}

Sebelum kegiatan pembelajaran dimulai guru menanyakan kabar anak, kemudian menyiapkan anak untuk belajar, mengucapkan salam, membimbing anak untuk berdoa sebelum belajar.

Hasil observasi guru sesuai dengan pedoman lembar observasi sebanyak 14 aspek yang harus dicapai oleh guru. Pada siklus II skor yang dicapai oleh guru dari 14 aspek hanya 13 http://ejurnal.binawakya.or.id/index.php/MBI 
aspek atau 92,85\% aspek yang tercapai diantaranya sebagai berikut: (1) guru menyatakan sesuatu yang menenangkan kelas, (2) guru mengucapkan salam, (3) guru menyampaikan tugas yang akan di lakukan, (4) guru menyampaikan tema dan sub tema, (5) guru menyiapkan media, (6) guru memperlihatkan dan menjelaskan media yang akan digunakan, (7) guru memberikan bimbingan kepada anak dalam melakukan permainan, (8) guru memberikan contoh kepada anak dalam melakukan permainan bola estafet, (9) guru menyimpulkan kegiatan yang dilakukan, (10) guru menyampaikan tujuan pembelajaran, (11) guru mengadakan tanya jawab, (12) guru memberikan motivasi, penguatan, serta penghargaan, (13) guru membimbing anak untuk pulang.

Untuk lebih jelasnya dapat dilihat dari histogram berikut:

\section{Gambar 3. Histogram Pengamatan Aktivitas Mengajar Guru Siklus II}

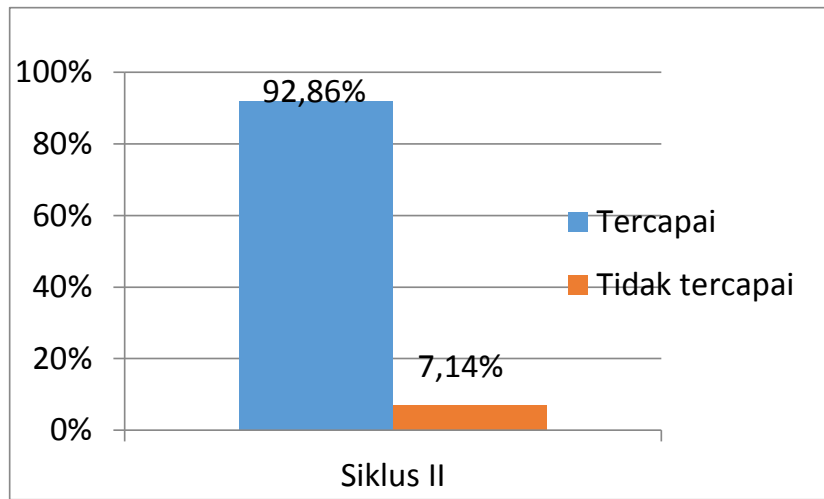

Berdasarkan diagram 3 dapat diketahui bahwa aktivitas mengajar guru pada siklus 1I mencapai sekitar 92,86\% sedangkan aktivitas mengajar guru yang tidak tercapai yaitu sekitar $7,14 \%$. Dengan demikian aktivitas mengajar guru pada siklus 1I sudah maksimal dikarenakan telah memenuhi standar ketercapaian aktivitas mengajar guru yang harus dicapai yaitu $85 \%$..

\section{Hasil Observasi Aktivitas Belajar Anak pada siklus II}

Observasi yang dilakukan pada aktivitas belajar anak pada siklus II yang diamati observer menggunakan lembar observasi aktivitas belajar anak yang terdiri dari 14 aspek. Pada siklus II hanya 12 aspek saja yang tercapai diantaranya: http://ejurnal.binawakya.or.id/index.php/MBI
(1) anak menjawab salam dari guru (2) anak berdoa sebelum belajar (3) anak berbaris di depan kelas, (4) anak siap untuk belajar, (5) mendengarkan nasihat yang disampaikan oleh guru, (6) anak memperhatikan guru menyampaikan kegiatan yang akan dilakukan, (7) anak memperhatikan media yang akan digunakan, (8) anak melakukan kegiatan permainan bola estafet setelah dicontohkan oleh guru, (9) anak memperhatikan guru memberikan contoh bermain bola estafet, (10) anak mengikuti arahan dari guru untuk pembagian kelompok (11) anak mendengarkan motivasi dari guru, (12) anak mendengarkan guru menyimpulkan kegiatan yang telah dilakukan.

Untuk lebih jelasnya dapat dilihat pada histogram berikut:

\section{Gambar 4. Histogram Hasil Observasi} Aktivitas Belajar Anak Siklus II

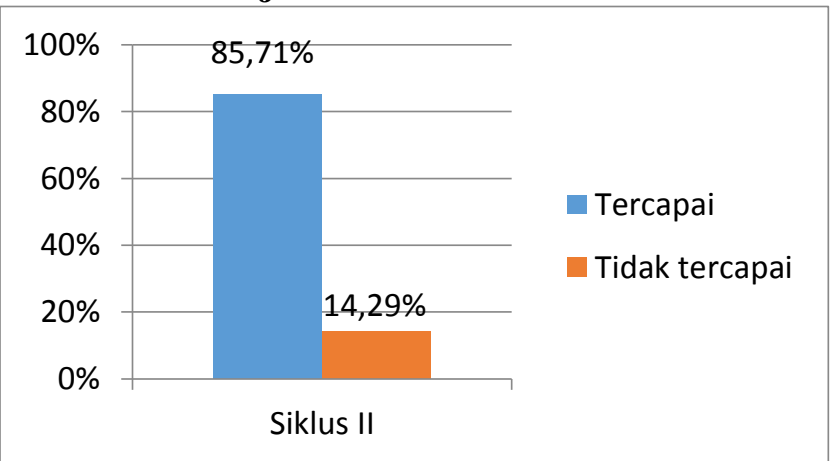

Berdasarkan diagram 4 dapat diketahui bahwa aktivitas belajar anak pada siklus II telah Mencapai mencapai 85,71\%, sedangkan aktivitas belajar anak yang tidak tercapai yaitu 14,29\%. Dengan demikian aktivitas belajar anak pada siklus II sudah maksimal karena telah memenuhi standar ketercapaian yaitu 85\%.Peneliti yang bekerjasama dengan guru kelompok B melakukan evaluasi pada akhir siklus. Evaluasi dilakukan untuk mengetahui perkembangan kemampuan motorik kasar anak melalui permainan bola estafet (bola ranting) setelah dilakukannya tindakan pada siklus II. Pencapaian keberhasilan anak dikelompokkan dalam empat kategori yaitu Berkembang Sangat Baik (BSB), Berkembang Sesuai Harapan (BSH), Mulai Berkembang (MB), serta Belum Berkembang (BB).

Vol.15 No.7 Februari 2021 
Tabel 4. Nilai Klasikal Motorik Kasar Anak Melalui Kegiatan Permaian Bola Estafet Siklus II

\begin{tabular}{|c|c|c|}
\hline Nilai & $\mathbf{F}$ & $\%$ \\
\hline $\begin{array}{l}\text { Berkembang } \\
\text { Sangat Baik } \\
\text { (BSH) Dengan } \\
\text { Skor }(3,50-4,00)\end{array}$ & 5 & $31,25 \%$ \\
\hline $\begin{array}{l}\text { Berkembang } \\
\text { Sesuai Harapan } \\
\text { (BSH) Dengan } \\
\text { Skor }(2,50-3,49)\end{array}$ & 10 & $62,5 \%$ \\
\hline $\begin{array}{l}\text { Mulai } \\
\text { Berkembang } \\
\text { (MB) Dengan } \\
\text { Skor }(1,50-2,49)\end{array}$ & 1 & $6,25 \%$ \\
\hline $\begin{array}{l}\text { Belum } \\
\text { Berkembang } \\
(B B) \quad \text { Dengan } \\
\text { Skor }(1,00-1,49)\end{array}$ & 0 & 0 \\
\hline Jumlah & 16 & $100 \%$ \\
\hline
\end{tabular}

(sumber: diolah dari data penelitian 2019)

Berdasarkan hasil yang ada pada tabel 4.2 dapat dilihat bahwa secara klasikal, meningkatkan kemampuan motorik kasar melalui permainan bola estafet di Kelompok B TK Kartika VI-15 Biak Kabupaten Biak Numfor pada tahap penilaian siklus II, rata-rata anak yang memperoleh nilai bintang $(* * * *)$ atau berkembang sangat baik (BSB) sebanyak 5 orang atau $31,25 \%$, anak yang memperoleh nilai bintang (***) atau Berkembang Sesuai Harapan sebanyak (BSH) sebanyak 10 orang anak atau $62,5 \%$, sedangkan anak yang memperoleh nilai bintang (**) atau Mulai Berkembang (MB) sebanyak 1 orang anak atau sekitar $6,25 \%$, dan tidak ada anak yang memperoleh nilai bintang (*) atau belum berkembang (BB). Berdasarkan hasil evaluasi tersebut, anak sudah dapat melaksanakan kegiatan dengan baik dan telah mencapai indikator kinerja yaitu $85 \%$

d. Refleksi

Berdasarkan hasil yang telah diperoleh pada pelaksanaan kegiatan untuk siklus II, dapat terlihat bahwa kegiatan penelitian yang dilaksanakan dalam meningkatkan

\section{Vol.15 No.7 Februari 2021}

kemampuan motorik kasar melalui permainan bola estafet di kelompok B TK Kartika VI-15 Biak Kabupaten Biak Numfor dimana terlihat bahwa pengimplementasian kegiatan permainan bola estafet dalam meningkatkan kemampuan motorik kasar anak telah mendapat hasil yang lebih baik dibanding siklus pertama, meskipun masih ada anak yang mendapat nilai bintang $(* *)$ sebanyak 1 orang anak atau $6,25 \%$.

Dilihat dari hasil perhitungan secara klasikal pada siklus II yaitu $93,75 \%$ anak telah mencapai indikator kinerja yang minimal 85\%. Anak memperoleh nilai BSB (Berkembang Sangat Baik) dan BSH (Berkembang Sesuai Harapan). Dengan demikian penelitian ini telah berhasil dilaksanakan, maka peneliti dan guru kelas khususnya kelompok B sepakat untuk tidak melanjutkan pada siklus berikutnya.

\section{Pembahasan}

Pelaksanaan penelitian ini terdiri dari dua siklus, dimana setiap siklus terdiri dari empat (4) kali pertemuan. Setiap pertemuan terdiri dari tiga tahap kegiatan yaitu tahap pertama kegiatan awal, yang kedua kegiatan inti,dan yang terakhir kegiatan akhir.

Kegiatan awal merupakan kegiatan pendahuluan yang dilakukan oleh guru sebelum masuk pada tema pembelajaran yang diawali dengan menanyakan kondisi anak, berdoa bersama, serta bernyanyi bersama.

Kegiatan inti yaitu guru menjelaskan materi pembelajaran sesuai dengan tema/sub tema. Contohnya seperti guru menjelaskan materi pembelajaran bola estafet dengan menggunakan bola estafet yang diberi lambang binatang pada saat itu, kemudian guru memberikan contoh kepada anak cara melakukan permainan bola estefet.

Kegiatan akhir yairu guru melakukan tanya jawab mengenai kegiatan yang telah dilakukan dari awal kegiatan sampai akhir kegiatan, guru juga meberikan motivasi-motivasi kepada anak, setelah itu barulah guru menyiapkan anak untuk pulang dengan menyanyikan lagu bersama, dan doa bersama. 
Pada observasi awal jika dibandingkan dengan pelaksanaan siklus I telah adanya peningkatan, namun belum mencapai indikator kinerja yang diharapkan, sehingga perlu dilakukan siklus II. Hal ini disebabkan karena pada pelaksanaan siklus I terdapat beberapa kekurangan guru serta anak dalam proses pembelajaran, sehingga perlu dilakukan suatu perbaikan siklus II agar indikator kinerja yang diharapkan dapat tercapai. Adapun kekurangan guru dalam proses pembelajaran yaitu kurangnya kemampuan peniliti dalam mengelola kelas, guru masih kurang dalam menyampaikan tujuan pembelajaran untuk anak, guru masih kurang menceritakan hal-hal yang dapat menarik perhatian anak agar anak lebih semangat dalam melakukan kegiatan, guru masih canggung dalam melaksanakan proses pembelajaran.

Berdasarkan kelemahan-kelemahan yang terjadi disiklus I guru berusaha untuk memperbaiki kelemahan-kelemahan yang terjadi seperti tidak akan merasa canggung lagi terhadap anak, guru juga akan menyampaikan tujuan pembelajaran, serta guru akan berusaha selalu menceritakan hal-hal yang menarik perhatian siswa agar menjadi semangat lagi dalam kegiatan pembelajaran.

Setelah dilakukan perbaikan pada siklus II, ternyata hasil yang diperoleh sangat mengalami peningkatan dari siklus I ke siklus II. Berdasarkan hasil yang diperoleh, dapat diketahui perbandingan jumlah anak yang telah mengetahui dan menguasai kegiatan permainan bola estafet (bola ranting) dengan kriteria BSB (Berkembang Sangat Baik) dan BSH (Berkembang Sesuai Harapan). Perolehan nilai BSB dan BSH sebelum tindakan atau observasi awal sebanyak 7 orang anak, setelah dilakukan siklus I mengalami peningkatan sebanyak 11 orang anak, dan setelah dilakukan kembali siklus II meningkat lagi menjadi 15 orang anak. Dengan ini dapat dilakukan analisis keberhasilan secara klasikal dan diperoleh hasil seperti yang ada pada histogram berikkut ini:
Gambar 5. Histogram Hasil Analisis Peningkatan Kemampuan Motorik Kasar Melalui Permainan Bola Estafet

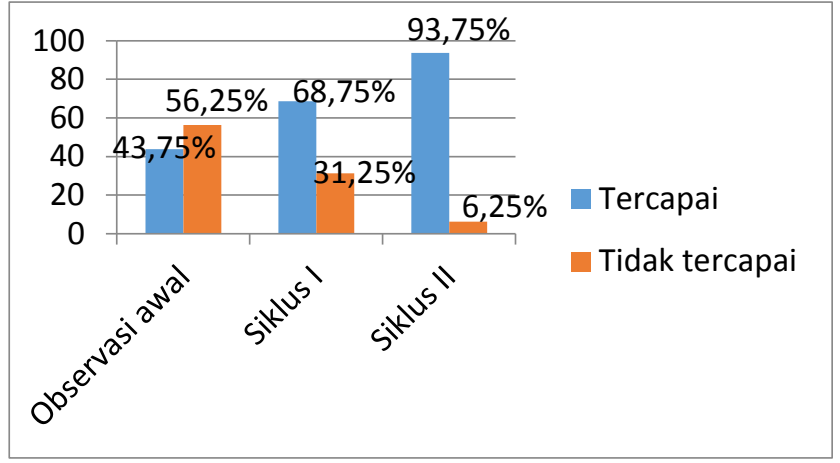

Selama kegiatan penelitian berlangsung, data hasil temuan yang diperoleh sebagaimana dideskripsikan pada halaman sebelumnya, dapat dikatakan bahwa kegiatan pembelajaran dalam kemampuan motorik kasar melalui permainan bola estafet yang dirancang, disusun, dan dilaksanakan secara baik dan optimal oleh pneliti yang bekerjasama dengan guru kelompok B TK Kartika VI-15 Biak Kabupaten Biak Numfor pada setiap pertemuan siklus I dan siklus II sangat memberikan manfaat pada anak didik. Dilihat dari observasi awal penelitian hanya mencapai 43,75\% dan pada tindakan siklus I anak sudah mengalami peningkatan meskipun hanya sedikit dari sebelumnya yaitu $68,75 \%$ dan pada tindakan siklus II mencapai presentase sebesar 93,75\% menunjukkan hasil yang lebih baik dari sebelumnya, karena indikator kinerja yang ditetapkan telah mencapai yaitu sebesar $85 \%$ maka penelitian ini dapat dihentikan.

\section{PENUTUP}

\section{Kesimpulan}

Observasi awal anak didik yang memperoleh nilai ketuntasan secara klasikal $43,75 \% .7$ orang yang mendapat nilai $(* * *)$ atau Berkembang Sesuai Harapan (BSH). Pada siklus I mencapai $68,75 \%$ dimana hanya 11 orang anak yang mendapat nilai $(* * *)$ atau Berkembang Sesuai Harapan. Selanjutnya pada siklus II diperoleh nilai ketuntasan secara klasikal $93,75 \%$. Dimana $31,25 \%$ atau 5 orang anak didik yang mendapat nilai (****) atau Berkembang Sangat Baik (BSB) dan 62,5\% atau 11 orang anak 
didik mendapat nilai $(* * *)$ atau Berkembang Sesuai Harapan (BSH) dan anak yang mendapat nilai (**) atau Mulai Berkembang (MB) sebanyak 1 orang anak didik atau $6,25 \%$.

Hasil observasi aktivitas mengajar guru pada sikluls I memperoleh persentase keberhasilan sebesar $71,43 \%$ dan hasil observasi aktivitas belajar anak didik pada siklus I memperoleh presentase keberhasilan 64,29\%. Selanjutnya pada siklus II aktivitas mengajar guru memperoleh presentase keberhasilan sebesar $92,86 \%$ dan hasil aktivitas observasi aktivitas belajar anak sebesar $85,71 \%$.

\section{Saran}

Setelah melaksanakan tindakan penelitian maka peneliti menyarankan hal-hal diantaranya dalam pelaksanaan pembelajaran maka hendaknya mempertimbangkan materi, media, dan strategi yang tepat untuk anak didik dan guru dituntut untuk selalu kreatif dan inovatif dalam melaksanakan kegiatan-kegiatan yang dapat meningkatkan potensi anak didik.

\section{DAFTAR PUSTAKA}

[1] Decaprio, R. 2013. Aplikasi teori pembelajaran motorik di sekolah. Yogyakarta: Diva Press.

[2] Depdiknas. 2003. Undang-Undang RI No. 20 Tahun 2003. Sistematis Pendidikan Nasional Jakarta: Citra Umbara.

[3] Eni, Ermawati. 2015. Upaya Meningkatkan Motorik Kasar Pada Anak Melalui Permainan Balap Karung Estafet Pada Kelompok BI Paud Supriyadi Semarang. www.ipb. Respositori.com.

[4] Fadillah, Muhammad dan Lilif Mualifatu Khorida. 2013. Pendidikan Karakter Anak Usia Dini Konsep Dan Aplikasinya Dalam PAUD. Yogyakarta: Ar-Ruzz Media.

[5] Guthrie, M. (2008). Sukses Melatih Atletik.Yogyakarta: PT Pustaka Insan Madani.

[6] Samsudin. (2008). Pembelajaran Motorik di Taman Kanak-Kanak. Jakarta: Prenada Media Group.
[7] Santrock, J.W. (2009). Psikologi Pendidikan Edisi 3 Buku 2.Terjemahan: Diana Angelica. Jakarta: Salemba Humanika.

[8] Saputra, Yudha. M \& Rudyanto 2005. Pembelajaran Kooperatif Untuk Meningkatkan Keterampilan Anak TK. Jakarta: Departemen Pendidikan.

[9] Sujiono, Bambang. 2008. Metode Pengembangan Fisik. Jakarta: Universitas Terbuka.

[10] Sumantri, MS. 2005. Model Pengembangan Keteranpilan Motorik Anak Usia Dini. Jakarta :Depdiknas

[11]Syafi'i. 2007. Psikologi Perkembangan Anak Dan Remaja. Bandung: PT Remaja Rosdakarya.

[12] Yusuf, Syamsu dan Nani Sugandi. 2016. Perkembangan Peserta Didik. Jakarta: PT. Raja Gravindo Persada. 